\title{
Interactive comment on "Inter-comparison of the Elemental and Organic Carbon Mass Measurements from Three North American National Long-term Monitoring Networks" by Tak W. Chan et al.
}

Tak W. Chan et al.

tak.chan@canada.ca

Received and published: 18 July 2019

The comment was uploaded in the form of a supplement:

https://www.atmos-meas-tech-discuss.net/amt-2019-104/amt-2019-104-AC1-

supplement.pdf 